\title{
Effect of $\mathrm{BaSi}_{2}$ template growth duration on the generation of defects and performance of $\mathbf{p}-\mathrm{BaSi}_{2} / \mathrm{n}-\mathrm{Si}$ heterojunction solar cells
}

\author{
Suguru Yachi, Ryota Takabe, Tianguo Deng, Kaoru Toko, and Takashi Suemasu* \\ Institute of Applied Physics, University of Tsukuba, Tsukuba, Ibaraki 305-8573, Japan \\ *Email: suemasu@bk.tsukuba.ac.jp
}

\begin{abstract}
We investigated the effect of $\mathrm{BaSi}_{2}$ template growth duration $\left(t_{\mathrm{RDE}}=0-20 \mathrm{~min}\right)$ on the defect generation and performance of $\mathrm{p}-\mathrm{BaSi}_{2} / \mathrm{n}$-Si heterojunction solar cells. The $\mathrm{p}-\mathrm{BaSi}_{2}$ layer grown by molecular beam epitaxy (MBE) was $15 \mathrm{~nm}$ thick with a hole concentration of $2 \times 10^{18} \mathrm{~cm}^{-3}$. The conversion efficiency $\eta$ increased for films grown at long $t_{\mathrm{RDE}}$, owing to improvements of the open-circuit voltage $\left(V_{\mathrm{OC}}\right)$ and fill factor $(F F)$, reaching a maximum of $\eta=8.9 \%$ at $t_{\mathrm{RDE}}=$ 7.5 min. However, $\eta$ decreased at longer and shorter $t_{\mathrm{RDE}}$ owing to lower $V_{\mathrm{OC}}$ and $F F$. Using deep-level transient spectroscopy, we detected a hole trap level $190 \mathrm{meV}$ above the valence band maximum for the sample grown without the template $\left(t_{\mathrm{RDE}}=0 \mathrm{~min}\right)$. An electron trap level $106 \mathrm{meV}$ below the conduction band minimum was detected for a sample grown with $t_{\mathrm{RDE}}$ $=20 \mathrm{~min}$. The trap densities for both films were $(1-2) \times 10^{13} \mathrm{~cm}^{-3}$. The former originated from the diffusion of $\mathrm{Ba}$ into the $\mathrm{n}$-Si region; the latter originated from defects in the template layer.
\end{abstract}


The crystalline qualities of the template and MBE-grown layers were discussed. The root-meansquare surface roughness of the template reached a minimum of $0.51 \mathrm{~nm}$ at $t_{\mathrm{RDE}}=7.5 \mathrm{~min}$. The $a$-axis orientation of $\mathrm{p}-\mathrm{BaSi}_{2}$ thin films degraded as $t_{\mathrm{RDE}}$ exceeded $10 \mathrm{~min}$. In terms of $\mathrm{p}-\mathrm{BaSi}_{2}$ crystalline quality and solar cell performance, the optimum $t_{\mathrm{RDE}}$ was determined to be $7.5 \mathrm{~min}$, corresponding to approximately $4 \mathrm{~nm}$ in thickness. 


\section{Introduction}

Photovoltaic solar cells have been widely studied as an important device for the generation of electricity. The leading material used in photovoltaics is crystalline silicon (c-Si). More than 90\% of installed solar cells are based on c-Si [1-3]. Yoshikawa et al. have recently reported a record efficiency $(\eta)$ exceeding 26\% [4]. However, this value of $\eta$ is already close to the theoretical Shockley-Queisser limit [5]. The bandgap $\left(E_{\mathrm{g}}\right)$ of $\mathrm{c}-\mathrm{Si}$ is $1.1 \mathrm{eV}$, which is smaller than the optimum $E_{\mathrm{g}}$ of approximately $1.4 \mathrm{eV}$ for a single-junction solar cell. To achieve high $\eta$ at a low cost, various thin-film solar cell materials, such as $\mathrm{Cu}(\mathrm{In}, \mathrm{Ga}) \mathrm{Se}_{2}[6-10], \mathrm{CdTe}[11,12]$, and perovskite solar cells [13-18], have attracted considerable attention because of their higher optical absorption coefficient $(\alpha)$ and larger $E_{\mathrm{g}}$ than those of $\mathrm{c}-\mathrm{Si}$. However, many of these materials make use of rare and/or toxic elements. Si thin-film solar cells have also been studied; however, it is difficult to achieve $\eta$ higher than $20 \%$ because of the small $\alpha$ value of Si [19-23]. An ideal alternative absorbing material should have a high $\alpha$, a long minority-carrier lifetime, and an $E_{\mathrm{g}}$ value close to $1.4 \mathrm{eV}$. Orthorhombic barium disilicide $\left(\mathrm{BaSi}_{2}\right)$ has all these properties [24]. $\mathrm{BaSi}_{2}$ can be grown epitaxially on a $\mathrm{Si}(111)$ substrate with three epitaxial variants rotated by $120^{\circ}$ from each other around the surface normal [25]. Furthermore, $\mathrm{BaSi}_{2}$ has a bandgap of $1.3 \mathrm{eV}[26,27]$ and its $\alpha$ value is $3 \times 10^{4} \mathrm{~cm}^{-1}$ at $1.5 \mathrm{eV}$, which is more than 50 times larger than that of $\mathrm{c}-\mathrm{Si}$, despite the indirect bandgap of $\mathrm{BaSi}_{2}[28,29]$. Undoped $\mathrm{n}-\mathrm{BaSi}_{2}$ exhibits a minoritycarrier diffusion length $L$ of ca. $10 \mu \mathrm{m}$ [30] and a minority-carrier lifetime of ca. $10 \mu \mathrm{s}[31,32]$, 
which are sufficiently large for thin-film solar cell applications. Impurity doping of $\mathrm{BaSi}_{2}$ enables control over the carrier type and carrier concentration to enable the fabrication of $\mathrm{BaSi}_{2}$ p-n junction diodes [33-35]. Owing to the large $L$ and $\alpha$ values, a value of $\eta$ greater than $25 \%$ can be expected from a 2- $\mu$ m-thick $\mathrm{BaSi}_{2} \mathrm{p}$-n junction diode [36]. Other types of solar cells such as $\mathrm{BaSi}_{2}$ nanowires and $\mathrm{BaSi}_{2}$ /perovskite stacked layers have also been proposed [37-39]. Prior to attempting to develop a $\mathrm{BaSi}_{2}$ homojunction solar cell, we fabricated $\mathrm{p}-\mathrm{BaSi} 2 / \mathrm{n}-\mathrm{Si}$ heterojunction solar cells and achieved a value of $\eta$ approaching 10\% [40-42]. This device structure represents a suitable configuration for investigating defects around the $\mathrm{BaSi}_{2} / \mathrm{Si}$ heterointerface. For growth of $\mathrm{BaSi}_{2}$ films on $\mathrm{Si}(111)$, we used a two-step growth technique. First, a very thin $\mathrm{BaSi}_{2}$ template layer was grown by Ba deposition on a heated $\mathrm{Si}$ substrate by reactive deposition epitaxy (RDE). This template layer acted as a seed crystal for the subsequent growth of a $\mathrm{BaSi}_{2}$ layer by the co-deposition of $\mathrm{Ba}$ and $\mathrm{Si}$ by molecular beam epitaxy (MBE) [25]. This thin template layer approach expands the range of material systems possible, not only for $\mathrm{BaSi}_{2}[25]$ but also for other silicides, such as $\beta-\mathrm{FeSi}_{2}[43,44]$. Furthermore, it has been reported that the $\beta$-FeSi 2 template layer reduces the diffusion of $\mathrm{Fe}$ atoms into the Si substrate during MBE [45], implying that the template layer has a well-defined silicide/Si heterointerface, suitable for solar cell applications. However, there have been no reports to date on defects that occur at the $\mathrm{BaSi}_{2} / \mathrm{Si}$ interface, induced by several factors such as the diffusion of $\mathrm{Ba}$ into the $\mathrm{Si}$ and differences in the crystal structure and lattice constants of the two layers. In this work, 
we investigated the optimum template growth duration $\left(t_{\mathrm{RDE}}\right)$ to determine the appropriate template thickness and discuss the effect of $t_{\mathrm{RDE}}$ on the crystalline quality of the $\mathrm{p}-\mathrm{BaSi}_{2}$ thin films and the resulting performance of $\mathrm{p}-\mathrm{BaSi}_{2} / \mathrm{n}-\mathrm{Si}$ heterojunction solar cells.

\section{Experimental method}

We used an ion-pumped MBE system (R-DEC) equipped with an electron-beam (EB) evaporation source for $\mathrm{Si}$ and standard Knudsen cells for $\mathrm{Ba}$ and $\mathrm{B}$. We grew B-doped p-BaSi 2 epitaxial films on $\mathrm{n}-\mathrm{Si}(111)$ (resistivity $\rho=1-4 \Omega \mathrm{cm}$ ) to fabricate $\mathrm{p}-\mathrm{BaSi}_{2} / \mathrm{n}$-Si heterojunction solar cells. Before the growth, the Si substrates were prepared as follows. The substrates were washed by RCA cleaning steps, including the removal of organic and metallic contaminants. The substrates were then heated at $900{ }^{\circ} \mathrm{C}$ for $30 \mathrm{~min}$ in ultrahigh vacuum to remove the protective $\mathrm{SiO}_{2}$ layers. We first deposited $\mathrm{Ba}$ on a heated $\mathrm{n}-\mathrm{Si}(111)$ substrate at $500{ }^{\circ} \mathrm{C}$ by $\mathrm{RDE}$ to form a $\mathrm{BaSi}_{2}$ template layer. Next, we evaporated $\mathrm{Ba}$ and $\mathrm{Si}$ at $600{ }^{\circ} \mathrm{C}$ by $\mathrm{MBE}$ to form a 15 nm-thick p-BaSi 2 epitaxial layer. During the MBE growth, we also supplied B as a p-type dopant to ensure the hole concentration $p=2 \times 10^{18} \mathrm{~cm}^{-3}$. Then, we formed a 3 -nm-thick amorphous Si capping layer at $180{ }^{\circ} \mathrm{C}$ to prevent the surface oxidation of $\mathrm{p}-\mathrm{BaSi}_{2}$ [46]. Finally, 80-nm-thick indium-tin-oxide (ITO) surface electrodes of $1 \mathrm{~mm}$ diameter and $\mathrm{Al}$ rear electrodes were formed by sputtering to evaluate the electrical characteristics. We fixed the MBE growth duration at $12 \mathrm{~min}$ (ca. $15 \mathrm{~nm}$ ) and changed the RDE growth duration ( $\left.t_{\mathrm{RDE}}\right)$ from 0 to $20 \mathrm{~min}$. 
We used X-ray reflectivity (XRR) measurements to evaluate the layer thickness and the crystalline quality was characterized by reflection high-energy electron diffraction (RHEED), out-of-plane $(\theta-2 \theta)$ and in-plane $\left(\varphi-2 \theta_{\chi}\right)$ X-ray diffraction (XRD), and $\omega$-scan X-ray rocking-curve measurements with $\mathrm{CuK} \alpha$ radiation. We used a $\mathrm{Ge}(220)$ single crystal monochromator for the X-rays. Surface morphologies were observed by atomic force microscopy (AFM). Current density versus voltage $(J-V)$ characteristics were measured under standard AM1.5, $100 \mathrm{~mW} / \mathrm{cm}^{2}$ illumination at $25^{\circ} \mathrm{C}$. Photoresponse spectra were measured at room temperature by a lock-in technique using a xenon lamp with a 25 -cm-focal-length single monochromator (Bunko Keiki SM-1700A and RU-60N). The light intensity was calibrated with a pyroelectric sensor (Melles Griot 13PEM001/J). All measurements were performed using a mask with 1-mm-diameter holes. The deep-level transient spectroscopy (DLTS) measurements were performed in the temperature range of $80-300 \mathrm{~K}$ using an $1 \mathrm{MHz}$ capacitance-voltage meter (HP, 4280A) to evaluate the defects [47]. The depletion region stretched into the n-Si region owing to the large difference in carrier concentration between $\mathrm{p}-\mathrm{BaSi}_{2}\left(p=2 \times 10^{18} \mathrm{~cm}^{-3}\right)$ and $\mathrm{n}$-Si $\left(n \approx 2 \times 10^{15} \mathrm{~cm}^{-3}\right)$. Secondary ion mass spectrometry (SIMS) measurements were conducted with $\mathrm{O}_{2}{ }^{+}$ion to investigate the $\mathrm{Ba}$ diffusion into n-Si. When the SIMS measurements were performed from the front surface side, there is a possibility that primary $\mathrm{O}_{2}{ }^{+}$ions might push $\mathrm{Ba}$ atoms deeper into the $\mathrm{n}$-Si side, affecting the depth profile of $\mathrm{Ba}$ atoms. To avoid this effect, the SIMS measurements were performed from the back surface of the n-Si substrate. 


\section{Results and discussion}

Figure 1 shows the $t_{\mathrm{RDE}}$ dependence of the total measured $\mathrm{BaSi}_{2}$ thickness after MBE. The gray area corresponds to the RDE-grown layer thickness. We found that the $\mathrm{BaSi}_{2}$ thickness by $\mathrm{MBE}$ was approximately $15 \mathrm{~nm}$ in Fig. 1 . The thickness increased almost linearly with $t_{\mathrm{RDE}}$. The RDE-grown thickness reached $10 \mathrm{~nm}$ at $t_{\mathrm{RDE}}=20 \mathrm{~min}$.

Figure 2(a) shows the $J$ - $V$ characteristics under AM1.5 illumination and Fig. 2(b) shows external quantum efficiency ( $E Q E)$ spectra for samples grown with various $t_{\mathrm{RDE}}$ values. Among the various parameters, the open-circuit voltage ( $\left.V_{\mathrm{OC}}\right)$ changed considerably depending on $t_{\mathrm{RDE}}$, whereas there were no notable differences in the $E Q E$ spectra and thereby short-circuit current density $\left(J_{\mathrm{SC}}\right)$. To discuss what happens in these devices, solar cell parameters such as the series resistance $R_{\mathrm{S}}$ and the shunt resistance $R_{\mathrm{SH}}$ were derived using the following equation [48]:

$$
\frac{d V}{d J}=S R_{\mathrm{S}}+\frac{\not k_{\mathrm{B}} T}{q}\left[\frac{1-\left(S R_{\mathrm{SH}}\right)^{-1} d V / d J}{J+J_{S C}-\left(S R_{\mathrm{SH}}\right)^{-1} V}\right],
$$

where $q$ is the elementary charge, $\gamma$ is the diode ideality factor, $k_{\mathrm{B}}$ is the Boltzmann constant, $T$ is the absolute temperature, and $S$ is the device area. The solar cell parameters are summarized in Fig. 3. The conversion efficiency $\eta$ increased with $t_{\mathrm{RDE}}$, reaching a maximum of $8.9 \%$ at $t_{\mathrm{RDE}}$ $=7.5 \mathrm{~min}$, before decreasing at longer $t_{\mathrm{RDE}}$. The same trend was obtained for the $V_{\mathrm{OC}}$ and fill factor $(F F)$ as $t_{\mathrm{RDE}}$ was varied. The $t_{\mathrm{RDE}}$ of 7.5 min corresponded to an approximately $4 \mathrm{~nm}$ - 
thick $\mathrm{BaSi}_{2}$ layer, according to Fig. $1 . J_{\mathrm{SC}}$ gradually decreased at $t_{\mathrm{RDE}}>10 \mathrm{~min}$. Although $R_{\mathrm{SH}}$ was scattered, $R_{\mathrm{S}}$ became large at shorter and longer $t_{\mathrm{RDE}}$, affecting the $F F$. On the basis of these results, we determined the optimum $t_{\mathrm{RDE}}$ to be $7.5 \mathrm{~min}$ (thickness of ca. $4 \mathrm{~nm}$ ) from the viewpoint of solar cell performance.

To investigate the reasons for $\eta$ degradation for small and large $t_{\mathrm{RDE}}$, we performed DLTS measurements to evaluate the defect densities and their energy levels near the heterointerface. A schematic representation of the DLTS measurement is shown in Fig. 4(a). All voltages were applied to $\mathrm{p}-\mathrm{BaSi}_{2}$ with respect to $\mathrm{n}-\mathrm{Si}$. A forward filling pulse voltage $\left(V_{\mathrm{P}}\right)$ disturbs the steady-state reverse-bias condition, causing the electric field in the depletion region to decrease, which induces the defect levels to be recharged. When the voltage returns to its steady state, the defect levels begin to discharge by emitting trapped carriers through thermal emission, and the resultant time evolution of the capacitance change $S(T)$ is measured over various rate windows. DLTS allows the immediate determination of whether defects act as minority-carrier traps or majority-carrier traps from the sign of the DLTS signal. Positive signals indicate the presence of minority-carrier traps, and negative signals indicate the presence of majority-carrier traps. Figures $4(b)\left(b^{\prime}\right)-4(d)\left(d^{\prime}\right)$ show the DLTS spectra of the p$\mathrm{BaSi}_{2} / \mathrm{n}-\mathrm{Si}$ heterojunction solar cells grown with $t_{\mathrm{RDE}}=0,7.5$, and $20 \mathrm{~min}$. We set $V_{\mathrm{P}}$ at $1 \mathrm{~V}$ with a pulse width of $50 \mathrm{~ms}$. A reversed-biased voltage $\left(V_{\mathrm{R}}\right)$ was set at $-3 \mathrm{~V}$ in Figs. 4(b)-4(d), and $-0.01 \mathrm{~V}$ in Figs. $4\left(\mathrm{~b}^{\prime}\right)-4\left(\mathrm{~d}^{\prime}\right)$. The rate window was $0.5-128 \mathrm{~ms}$. At $V_{\mathrm{R}}=-3 \mathrm{~V}$, the depletion 
region stretched approximately $1.5 \mu \mathrm{m}$ from the interface towards the $\mathrm{n}$-Si side; however, it remained close to the heterointerface at $V_{\mathrm{R}}=-0.01 \mathrm{~V}$. We detected one minority carrier (hole) trap (H1) in the $t_{\mathrm{RDE}}=0$ min film, as shown in Fig. 4(b), and a majority carrier (electron) trap (E1) in the $t_{\mathrm{RDE}}=20$ min film, shown in Fig. 4(d'), explaining the degradation of $\eta$ for small and large $t_{\mathrm{RDE}}$. No other distinct defects were observed. Figure 5 shows Arrhenius plots of these two traps $\mathrm{H} 1$ and E1. The hole trap level H1 was located $190 \mathrm{meV}$ above the valence band maximum (VBM), and the trap density was $N_{\mathrm{T}}^{\mathrm{h}}=2.2 \times 10^{13} \mathrm{~cm}^{-3}$. The electron trap level E1 was located $106 \mathrm{meV}$ below the conduction band minimum (CBM), and the trap density was $N_{\mathrm{T}}^{\mathrm{e}}=1.5 \times 10^{13} \mathrm{~cm}^{-3}$ for E1. The DLTS measurements revealed that the samples without the $\mathrm{BaSi}_{2}$ template $\left(t_{\mathrm{RDE}}=0 \mathrm{~min}\right)$ featured a hole trap level $\mathrm{H} 1$ in the $\mathrm{n}-\mathrm{Si}$ bulk region, and that film growth based on the thickest $\mathrm{BaSi}_{2}$ template $\left(t_{\mathrm{RDE}}=20 \mathrm{~min}\right)$ featured an electron trap level $\mathrm{E} 1$ near the heterointerface.

Figure 6 shows the SIMS depth profiles of $\mathrm{Ba}$ and Si atoms of the samples grown with $t_{\mathrm{RDE}}=1$ and $10 \mathrm{~min}$. The plots in red show the profiles of $\mathrm{Ba}$ atoms and the black plots denote those of Si atoms. Reference samples with a controlled number of Ba atoms doped in Si have yet to be prepared. Hence, we used the SIMS signal intensity to compare these two samples. At a depth $>60 \mathrm{~nm}$, the SIMS intensity in the sample grown with $t_{\mathrm{RDE}}=1$ min was almost one order of magnitude larger than that in the sample grown with $t_{\mathrm{RDE}}=10 \mathrm{~min}$. We can therefore assume that the diffusion of $\mathrm{Ba}$ atoms into the $\mathrm{n}-\mathrm{Si}$ was suppressed in the sample grown with 
$t_{\mathrm{RDE}}=10$ min compared with that for the sample grown with $t_{\mathrm{RDE}}=1 \mathrm{~min}$. Thus, the RDEgrown template acts as a diffusion barrier for $\mathrm{Ba}$ atoms, as is the case in $\beta-\mathrm{FeSi}_{2}$ [45]. We therefore ascribe the hole trap level (H1), observed in Fig. 4(b), to the diffusion of Ba atoms into $\mathrm{n}-\mathrm{Si}$.

To understand why the diffusion of Ba atoms into the Si substrate was promoted for the template at $t_{\mathrm{RDE}}=1 \mathrm{~min}$, we observed the surface morphologies of the RDE-grown layers. Figure 7 shows AFM topographic images $\left(2 \times 2 \mu \mathrm{m}^{2}\right)$ of the RDE-grown $\mathrm{BaSi}_{2}$ surfaces grown at (a) $t_{\mathrm{RDE}}=1 \mathrm{~min}$, (b) $t_{\mathrm{RDE}}=7.5 \mathrm{~min}$, and (c) $t_{\mathrm{RDE}}=15 \mathrm{~min}$. The cross-sectional profiles along the broken lines are also shown. The root-mean-square (RMS) roughness values of the RDEgrown $\mathrm{BaSi}_{2}$ were $0.74,0.42$, and $1.58 \mathrm{~nm}$ at $t_{\mathrm{RDE}}=1,7.5$, and $15 \mathrm{~min}$, respectively. The smallest value was obtained at $t_{\mathrm{RDE}}=7.5 \mathrm{~min}$. We found a large number of small $\mathrm{BaSi}_{2}$ islands on the $\mathrm{Si}(111)$ surface at $t_{\mathrm{RDE}}=1 \mathrm{~min}$ in Fig. 7(a), indicating that the template did not cover the entire $\mathrm{Si}$ surface. Hence, $\mathrm{p}-\mathrm{BaSi}_{2}$ was directly grown on a large part of the $\mathrm{Si}(111)$ surface by MBE. The diffusion of $\mathrm{Ba}$ atoms into the Si substrate is promoted at higher temperatures. In this study, RDE and MBE growths were conducted at 500 and $600{ }^{\circ} \mathrm{C}$, respectively. Hence, it can be safely stated that Ba diffusion during MBE is suppressed by a continuous template layer, as indicated by the SIMS profile in Fig. 6. As $t_{\mathrm{RDE}}$ was increased further to $7.5 \mathrm{~min}$, the entire surface of the Si became covered with the $\mathrm{BaSi}_{2}$ template, as shown in Fig. 7(b). Once the Si surface was covered with the $\mathrm{BaSi}_{2}$ template at $500{ }^{\circ} \mathrm{C}$, the diffusion of $\mathrm{Ba}$ atoms into $\mathrm{Si}$ was 
likely to be suppressed even during the subsequent MBE growth at $600{ }^{\circ} \mathrm{C}$. When $t_{\mathrm{RDE}}$ was increased further to $15 \mathrm{~min}$, the RMS value increased considerably to $1.58 \mathrm{~nm}$, and many valleys with depths of approximately $2 \mathrm{~nm}$ appeared on the template, as seen in Fig. 7(c). We next consider the origin of the E1 level detected at $V_{\mathrm{R}}=-0.01 \mathrm{~V}$ for the sample grown with $t_{\mathrm{RDE}}=20 \mathrm{~min}$ in Fig. $4\left(\mathrm{~d}^{\prime}\right)$. The electrical properties of the RDE-grown $\mathrm{BaSi}_{2}$ template are unclear; however, it is reasonable to assume that some portion of the depletion region stretched toward the undoped RDE-grown template at $V_{\mathrm{R}}=-0.01 \mathrm{~V}$, because the RDEgrown $\mathrm{BaSi}_{2}$ thickness was approximately $10 \mathrm{~nm}$ at $t_{\mathrm{RDE}}=20 \mathrm{~min}$ in Fig. 1 . The RDE-grown $\mathrm{BaSi}_{2}$ template was considered to have n-type conductivity because undoped $\mathrm{BaSi}_{2}$ often presents n-type properties with an electron concentration of approximately $10^{16} \mathrm{~cm}^{-3}[26,49]$. Figure 7(c) shows that the surface of the $\mathrm{BaSi}_{2}$ template at $t_{\mathrm{RDE}}=20 \mathrm{~min}$ was very rough. We attribute such a rough surface to the supply of Si atoms from the Si substrate being deficient as the $\mathrm{BaSi}_{2}$ thickness increased. Kumar et al. demonstrated by first-principles calculation that $\mathrm{Si}$ vacancy is a predominant defect in $\mathrm{BaSi}_{2}$ [50]. Thereby, the E1 level can be interpreted to originate from Si point defects induced in the template at $t_{\mathrm{RDE}}=20 \mathrm{~min}$.

Because of the differences in the carrier concentrations of $\mathrm{p}-\mathrm{BaSi}_{2}$ and $\mathrm{n}-\mathrm{Si}$, the depletion region did not stretch toward the $\mathrm{p}-\mathrm{BaSi}_{2}$ region at $V_{\mathrm{R}}<0$, and thus the characterization of defects was limited to the region near the interface and the n-Si bulk in the present DLTS measurements. Here, we discuss the effect of the crystalline quality of the 
template on the MBE-grown overlayers. Figure 8(a) shows the RMS surface roughness values of the grown p-BaSi 2 films as a function of $t_{\mathrm{RDE}}$, and Fig. 8(b) shows the full widths at half maximum (FWHMs) of the $\mathrm{BaSi}_{2}(600)$ diffraction intensity as a function of $t_{\mathrm{RDE}}$. The RMS decreased as $t_{\mathrm{RDE}}$ was increased and became a minimum at approximately $t_{\mathrm{RDE}}=6.5,7.5$, and $10 \mathrm{~min}$, and then increased. This trend was almost the same as that of an RDE-grown $\mathrm{BaSi}_{2}$ template, as shown in Fig. 7. We speculate that there is a possibility that such rough surfaces of p-BaSi 2 might increase $R_{\mathrm{S}}$ because of insufficient contact between ITO and $\mathrm{p}-\mathrm{BaSi}_{2}$ for samples grown at shorter and longer $t_{\mathrm{RDE}}$, leading to the decrease in $F F$ as shown in Fig. 3. The FWHM increased with $t_{\mathrm{RDE}}$, most notably for $t_{\mathrm{RDE}}>10 \mathrm{~min}$, indicating that the crystal orientation degraded as $t_{\mathrm{RDE}}$ was prolonged. Thus, a $t_{\mathrm{RDE}}$ of $6.5-10 \mathrm{~min}$ is optimal from the viewpoint of $\mathrm{p}-\mathrm{BaSi}_{2}$ crystalline quality. These results suggest that the increase in FWHM with $t_{\mathrm{RDE}}$ is related to the lattice relaxation of $\mathrm{BaSi}_{2}$. Both the out-of-plane and in-plane lattice constants were calculated from the peak positions in the $\theta-2 \theta$ and $\varphi-2 \theta_{\chi}$ XRD patterns, respectively. Measurement errors were minimized with the use of the Nelson-Riley equation for the calculations [51]. Figures 9(a)-9(c) show the dependence of $\mathrm{BaSi}_{2} a-, b$-, and $c$-axis lattice constants of $\mathrm{BaSi}_{2}$ films on $t_{\mathrm{RDE}}$, respectively. The in-plane epitaxial relationships of $a$-axisoriented $\mathrm{BaSi}_{2}$ on $\mathrm{Si}(111)$ were $\mathrm{BaSi}_{2}[010] / / \mathrm{Si}[11 \overline{2}]$ and $\mathrm{BaSi}_{2}[001] / / \mathrm{Si}[\overline{1} 10]$. The blue broken lines show the lattice constants of $\mathrm{BaSi}_{2}$ bulk [52], the broken red line in Fig. 9(b) shows the interplanar distance of $\operatorname{Si}(11 \overline{2})$, and the broken green line in Fig. 9(c) denotes three times the 
interplanar distance of $\mathrm{Si}(110)$ [25]. The lattice constants $b$ and $c$ of the $\mathrm{BaSi}_{2}$ films almost lattice-matched with the $\mathrm{Si}(111)$ surface for short $t_{\mathrm{RDE}}$, meaning that $\mathrm{BaSi}_{2}$ was under in-plane compressive strain. As $t_{\mathrm{RDE}}$ was increased, $\mathrm{BaSi}_{2}$ relaxed, and the measured lattice constants $a$, $b$, and $c$ approached the bulk $\mathrm{BaSi}_{2}$ values. These results show that $\mathrm{BaSi}_{2}$ films at short $t_{\mathrm{RDE}}$ were strained and their lattices became relaxed as $t_{\mathrm{RDE}}$ was increased. In terms of both solar cell performance and the crystalline quality of $\mathrm{p}-\mathrm{BaSi}_{2}$, we conclude that the optimum template thickness was approximately $4 \mathrm{~nm}\left(t_{\mathrm{RDE}}=7.5 \mathrm{~min}\right)$.

\section{Conclusions}

We fabricated $\mathrm{p}-\mathrm{BaSi}_{2} / \mathrm{n}-\mathrm{Si}$ heterojunction solar cells and investigated the effect of $t_{\mathrm{RDE}}$ on defect formation and solar cell performance. The value of $\eta$ increased as $t_{\mathrm{RDE}}$ increased because of the improvements of $V_{\mathrm{OC}}$ and $F F$. The maximum value was $\eta=8.9 \%$ from a film grown with $t_{\mathrm{RDE}}=7.5$ min. We detected one hole trap (H1) located $190 \mathrm{meV}$ above the VBM with $N_{\mathrm{T}}^{\mathrm{h}}=$ $2.2 \times 10^{13} \mathrm{~cm}^{-3}$ in the $\mathrm{n}$-Si side of the sample grown without the template $\left(t_{\mathrm{RDE}}=0 \mathrm{~min}\right) . \mathrm{In}$ addition, one electron trap (E1) was located $106 \mathrm{meV}$ below the CBM with $N_{\mathrm{T}}^{\mathrm{e}}=1.5 \times 10^{13}$ $\mathrm{cm}^{-3}$, which was likely present in the RDE-grown template for the sample grown with a long $t_{\mathrm{RDE}}$ of $20 \mathrm{~min}$. The $\mathrm{H} 1$ and $\mathrm{E} 1$ traps were attributed to the diffusion of Ba atoms into the $\mathrm{n}-\mathrm{Si}$ and the degraded RDE template layer, respectively. On the basis of these results, the optimum $t_{\mathrm{RDE}}$ was determined to be $7.5 \mathrm{~min}(\mathrm{ca} .4 \mathrm{~nm})$ from the viewpoints of both solar cell performance 
and crystalline quality of the $\mathrm{p}-\mathrm{BaSi}_{2}$ films.

\section{Acknowledgments}

This work was financially supported by JSPS KAKENHI Grant Numbers 15H02237 and 17K18865. R.T. was financially supported by a Grant-in-Aid for JSPS Fellows (15J02139). 
[1] S. R. Wenham and M. A. Green, Prog. Photovoltaics 4, 3 (1996).

[2] M. A. Green, Prog. Photovoltaics 17, 183 (2009).

[3] V. V. Tyagi, N. A. A. Rahim, N. A. Rahim, and J. A. L. Selvaraj, Renewable Sustainable Energy Rev. 20, 443 (2013).

[4] K. Yoshikawa, H. Kawasaki, W. Yoshida, T. Irie, K. Konishi, K. Nakano, T. Uto, D. Adachi, M. Kanematsu, H. Uzu, and K. Yamamoto, Nat. Energy 2, 17302 (2017).

[5] W. Shockley, W. Hans, and H. J. Queisser, J. Appl. Phys. 32, 510 (1961).

[6] P. Jackson, D. Hariskos, R. Wuerz, O. Kiowski, A. Bauer, T. M. Friedlmeier, and M. Powalla, Phys. Status Solidi RL 9, 28 (2015).

[7] P. Jackson, D. Hariskos, E. Lotter, S. Paetel, R. Wuerz, R. Menner, W. Wischmann, and M. Powalla, Prog. Photovoltaics 19, 894 (2011).

[8] S. C. Riha, B. A. Parkinson, and A. L. Prieto, J. Am. Chem. Soc. 131, 12054 (2009).

[9] M. G. Panthani, V. Akhavan, B. Goodfellow, J. P. Schmidtke, L. Dunn, A. Dodabalapur, P. F. Barbara, and B. A. Korgel, J. Am. Chem. Soc. 130, 16770 (2008).

[10] I. Repins, M. A. Contreras, B. Egaas, C. DeHart, J. Scharf, C. L. Perkins, B. To, and R. Noufi, Prog. Photovoltaics 16, 235 (2008).

[11] S. Kim, B. Fisher, H. J. Eisler, and M. Bawendi, J. Am. Chem. Soc. 125, 11466 (2003).

[12] J. Britt and C. Ferelides, Appl. Phys. Lett. 62, 2851 (1993).

[13] J. Burschka, N. Pellet, S. J. Moon, R. H. Baker, P. Gao, M. K. Nazeeruddin, and M. Grätzel, 
Nature 499, 316 (2013).

[14] M. Liu, M. B. Johnston, and H. J. Snaith, Nature 501, 395 (2013).

[15] S. D. Stranks, G. E. Eperon, G. Grancini, C. Menelaou, M. J. P. Alcocer, T. Leijtens, L. M. Herz, A. Petrozza, and H. J. Snaith, Science 342, 341 (2013).

[16] M. M. Lee, J. Teuscher, T. Miyasaka, T. N. Murakami, and H. J. Snaith, Science 338, 643 (2012).

[17] H. S. Kim, C. R. Lee, J. H. Im, K. B. Lee, T. Moehl, A. Marchioro, S. J. Moon, R. H. Baker, J. H. Yum, J. E. Moser, M. Grätzel, and N. G. Park, Sci. Rep. 2, 591 (2012).

[18] A. Kojima, K. Teshima, Y. Shirai, and T. Miyasaka, J. Am. Chem. Soc. 131, 6050 (2009).

[19] T. Matsui, H. Sai, K. Saito, and M. Kondo, Prog. Photovoltaics 21, 1363 (2013).

[20] J. Müller, B. Rech, J. Springer, and M. Vanecek, Sol. Energy 77, 917 (2004).

[21] K. L. Chopra, P. D. Paulson, and V. Dutta, Prog. Photovoltaics 12, 69 (2004).

[22] A.V. Shah, H. Schade, M. Vanecek, J. Meier, E.V. Sauvain, N. Wyrsch, U. Kroll, C. Droz, and J. Bailat, Prog. Photovoltaics 12, 113 (2004).

[23] A. Shah, P. Torres, R. Tscharner, N. Wyrsch, and H. Keppner, Science 285, 692 (1999).

[24] T. Suemasu and N. Usami, J. Phys. D 50, 023001 (2017).

[25] Y. Inomata, T. Nakamura, T. Suemasu, and F. Hasegawa, Jpn. J. Appl. Phys. 43, L478 (2004).

[26] K. Morita, Y. Inomata, and T. Suemasu, Thin Solid Films 508, 363 (2006). 
[27] K. Toh, T. Saito, and T. Suemasu, Jpn. J. Appl. Phys. 50, 068001 (2011).

[28] M. Kumar, N. Umezawa, and M. Imai, J. Appl. Phys. 115, 203718 (2014).

[29] D. B. Migas, V. L. Shaposhnikov, and V. E. Borisenko, Phys. Status Solidi B 244, 2611 (2007).

[30] M. Baba, K. Toh, K. Toko, N. Saito, N. Yoshizawa, K. Jiptner, T. Sekiguchi, K. O. Hara, N. Usami, and T. Suemasu, J. Cryst. Growth 348, 75 (2012).

[31] K. O. Hara, N. Usami, K. Nakamura, R. Takabe, M. Baba, K. Toko, and T. Suemasu, Appl. Phys. Express 6, 112302 (2013).

[32] K. O. Hara, N. Usami, K. Toh, M. Baba, K. Toko, and T. Suemasu, J. Appl. Phys. 112, 083108 (2012).

[33] M. Kobayashi, Y. Matsumoto, Y. Ichikawa, D. Tsukada, and T. Suemasu, Appl. Phys. Express 1, 051403 (2008).

[34] M. A. Khan, K. O. Hara, W. Du, M. Baba, K. Nakamura, M. Suzuno, K. Toko, N. Usami, and T. Suemasu, Appl. Phys. Lett. 102, 112107 (2013).

[35] M. A. Khan, K. Nakamura, W. Du, K. Toko, N. Usami, and T. Suemasu, Appl. Phys. Lett. 104, 252104 (2014).

[36] T. Suemasu, Jpn. J. Appl. Phys. 54, 07JA01 (2015).

[37] A. Pokhrel, L. Samad, F. Meng, and S. Jin, Nanoscale 7, 17450 (2015).

[38] R. Vismara, O. Isabella, and M. Zeman, SPIE 9898, 98980J (2016).

[39] R. Vismara, O. Isabella, and M. Zeman, Opt. Express 25, A402 (2017). 
[40] S. Yachi, R. Takabe, K. Toko, and T. Suemasu, Jpn. J. Appl. Phys. 56, 05 DB03 (2017).

[41] S. Yachi, R. Takabe, H. Takeuchi, K. Toko, and T. Suemasu, Appl. Phys. Lett. 109, 072103 (2016).

[42] D. Tsukahara, S. Yachi, H. Takeuchi, R. Takabe, W. Du, M. Baba, Y. Li, K. Toko, N. Usami, and T. Suemasu, Appl. Phys. Lett. 108, 152101 (2016).

[43] R. Kuroda, Z. Liu, Y. Fukuzawa, Y. Suzuki, M. Osamura, S. Wang, N. Otogawa, T. Ootsuka, T. Mise, Y. Hoshino, Y. Nakayama, H. Tanoue, and Y. Makita, Thin Solid Films 461, 34 (2004). [44] M. Takauji, N. Seki, T. Suemasu, F. Hasegawa, and M. Ichida, J. Appl. Phys. 96, 2561 (2004).

[45] Z. Liu, Y. Suzuki, M. Osamura, T. Ootsuka, T. Mise, R. Kuroda, H. Tanoue, Y. Makita, S. Wang, Y. Fukuzawa, N. Otogawa, and Y. Nakayama, J. Appl. Phys. 95, 4019 (2004).

[46] R. Takabe, S. Yachi, W. Du, D. Tsukahara, H. Takeuchi, K. Toko, and T. Suemasu, AIP Adv. 6, 085107 (2016).

[47] D. V. Lang, J. Appl. Phys. 45, 3023 (1974).

[48] J. R. Sites and P. H. Mauk, Sol. Cells 27, 411 (1989).

[49] W. Du, M. Baba, K. Toko, K.O. Hara, K. Watanabe, T. Sekiguchi, N. Usami, and T. Suemasu, J. Appl. Phys. 115, 223701 (2014).

[50] M. Kumar, N. Umezawa, W. Zhou, and M. Imai, J. Mater. Chem. A 5, 25293 (2017).

[51] J. B. Nelson and D. P. Riley, Proc. Phys. Soc. 57, 160 (1945).

[52] H. Schäfer, K. H. Janzou, and A. Weiss, Angew. Chem., Int. Ed. 2, 393 (1963). 


\section{Figure captions}

Fig. 1. Dependence of $\mathrm{BaSi}_{2}$ layer thickness on $\mathrm{RDE}$ growth duration $\left(t_{\mathrm{RDE}}=0,1,5,6.5,7.5\right.$, 10,15 , and $20 \mathrm{~min}$ ), while the MBE growth duration was fixed at $12 \mathrm{~min}$.

Fig. 2. (a) $J-V$ characteristics of RDE films grown for various durations $\left(t_{\mathrm{RDE}}=0,1,5,6.5,7.5\right.$, 10, 15, and $20 \mathrm{~min}$ ) measured under AM1.5 illumination. (b) EQE spectra of films grown for various $t_{\mathrm{RDE}}$ values.

Fig. 3. Solar cell parameters: conversion efficiency $(\eta)$, open-circuit voltage $\left(V_{\mathrm{OC}}\right)$, short-circuit current $\left(J_{\mathrm{SC}}\right)$, fill factor $(F F)$, series resistance $\left(R_{\mathrm{S}}\right)$, and shunt resistance $\left(R_{\mathrm{SH}}\right)$ as a function of RDE growth duration $\left(t_{\mathrm{RDE}}=0,1,5,6.5,7.5,10,15\right.$, and $\left.20 \mathrm{~min}\right)$.

Fig. 4. (a) Principle of DLTS method and (b) DLTS spectra of p-BaSi $2 / n-S i$ solar cells grown with $t_{\mathrm{RDE}}=0,7.5$, and $20 \min (\mathrm{b})-(\mathrm{d})$ at $V_{\mathrm{R}}=-3 \mathrm{~V}$ and (b) $-\left(\mathrm{d}^{\prime}\right)$ at $V_{\mathrm{R}}=-0.01 \mathrm{~V}$. The $V_{\mathrm{P}}$ was set at $1 \mathrm{~V}$ with a pulse width of $50 \mathrm{~ms}$. The depletion region stretches mainly toward the $\mathrm{n}-\mathrm{Si}$ region because of the difference in carrier concentration between $\mathrm{p}-\mathrm{BaSi}_{2}$ and $\mathrm{n}-\mathrm{Si}$.

Fig. 5. Arrhenius plots of $\mathrm{H} 1$ and E1 levels observed in Fig. 4. 
Fig. 6. SIMS depth profiles of $\mathrm{Ba}$ (red) and Si (black) atoms in samples grown with $t_{\mathrm{RDE}}=1$ and $10 \mathrm{~min}$.

Fig. 7. Topographic AFM views $\left(2 \times 2 \mu \mathrm{m}^{2}\right)$ and cross-sectional profiles (along white broken lines) of RDE-grown $\mathrm{BaSi}_{2}$ surfaces at (a) $t_{\mathrm{RDE}}=1$, (b) $t_{\mathrm{RDE}}=7.5$, and (c) $t_{\mathrm{RDE}}=15 \mathrm{~min}$. The RMS surface roughness values are presented.

Fig. 8. (a) Dependence of $\mathrm{p}-\mathrm{BaSi}_{2} \mathrm{RMS}$ surface roughness on $t_{\mathrm{RDE}}$. The RMS value became a minimum at $t_{\mathrm{RDE}} \approx 7.5-10$ min. (b) Dependence of FWHM of $\mathrm{BaSi}_{2}(600)$ intensity on $t_{\mathrm{RDE}}$. The solid lines are a guide to the eyes.

Fig. 9. (a)-(c) Dependence of $\mathrm{BaSi}_{2}$ lattice constants $a, b$, and $c$, respectively, on $t_{\mathrm{RDE}}$. The broken blue lines show the lattice constants of bulk $\mathrm{BaSi}_{2}$ [52]. The broken red and blue lines denote the interplanar distance of $\operatorname{Si}(11 \overline{2})$ and three times the interplanar distance of $\operatorname{Si}(110)$, respectively. 


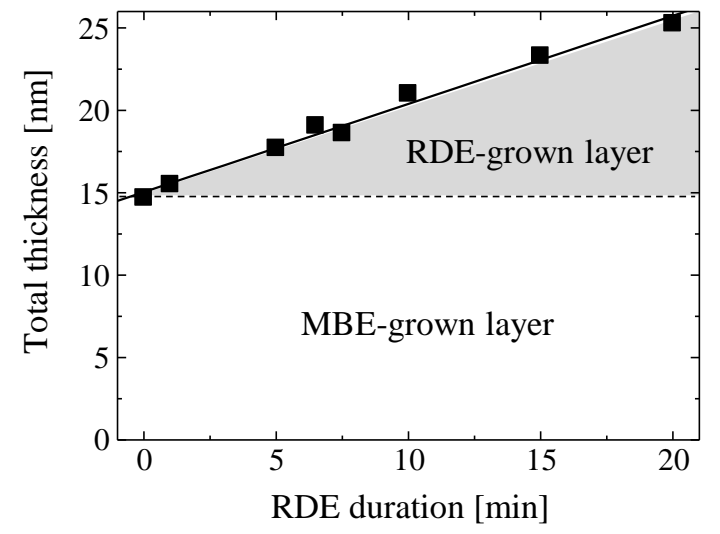

Fig. 1 
(a)

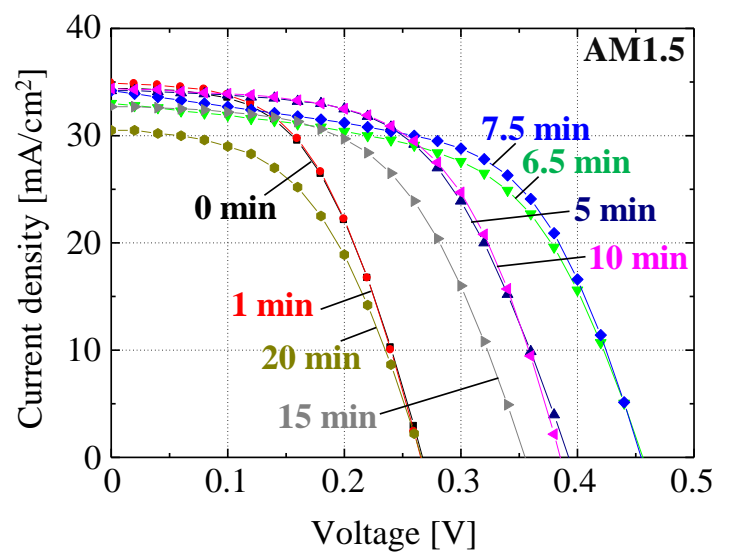

(b)

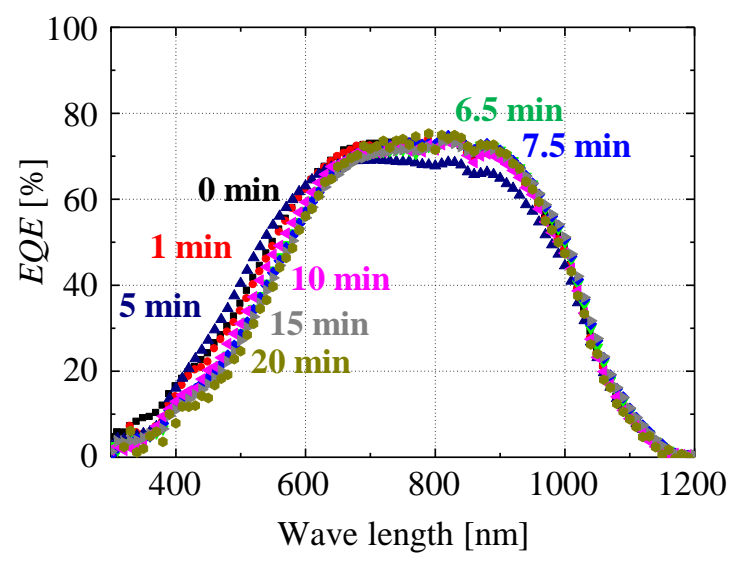

Fig. 2 


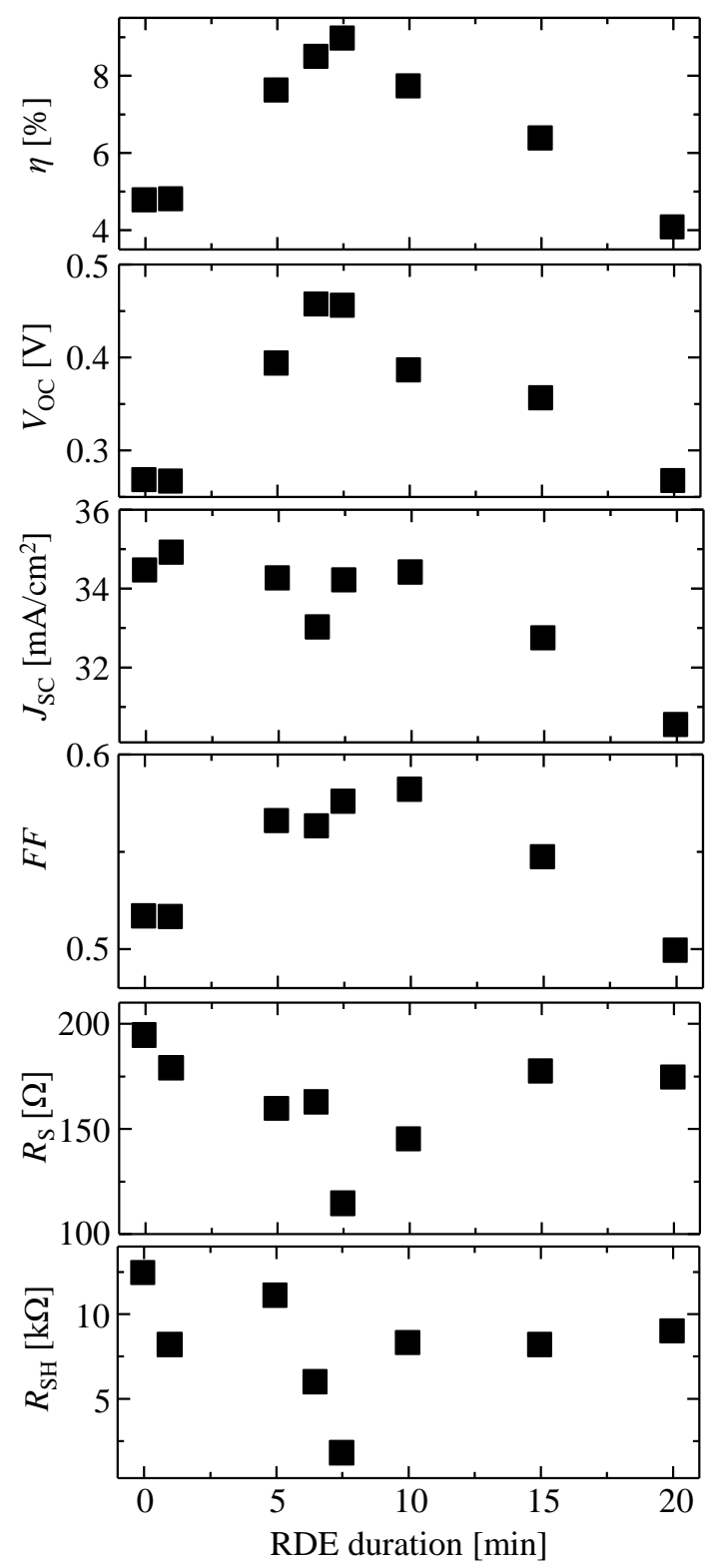

Fig. 3 
(a)
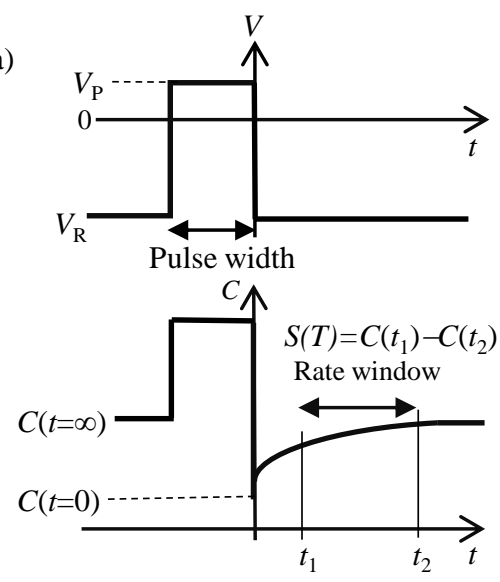

$V_{\mathrm{P}}=1 \mathrm{~V}, V_{\mathrm{R}}=-3 \mathrm{~V} \quad V_{\mathrm{P}}=1 \mathrm{~V}, V_{\mathrm{R}}=-0.01 \mathrm{~V}$

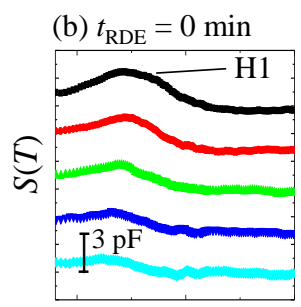

(b') $t_{\mathrm{RDE}}=0 \mathrm{~min}$
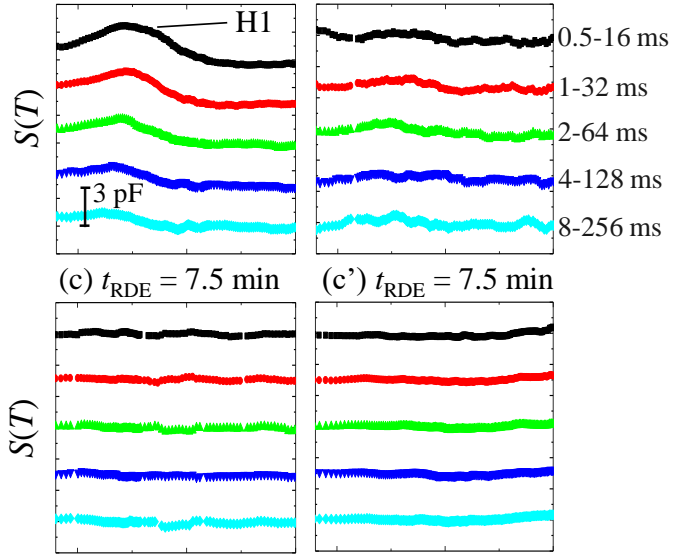

(c') $t_{\mathrm{RDE}}=7.5 \mathrm{~min}$

(d) $t_{\mathrm{RDE}}=20 \mathrm{~min}$

(d') $t_{\mathrm{RDE}}=20 \mathrm{~min}$

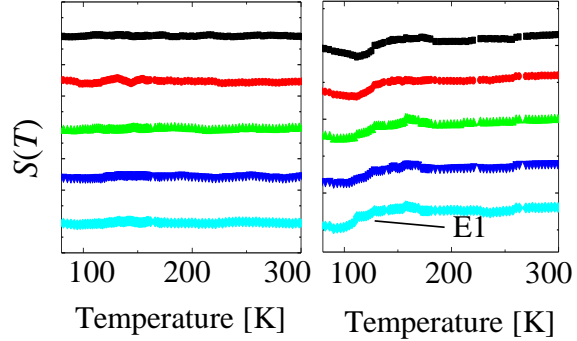

Fig. 4 


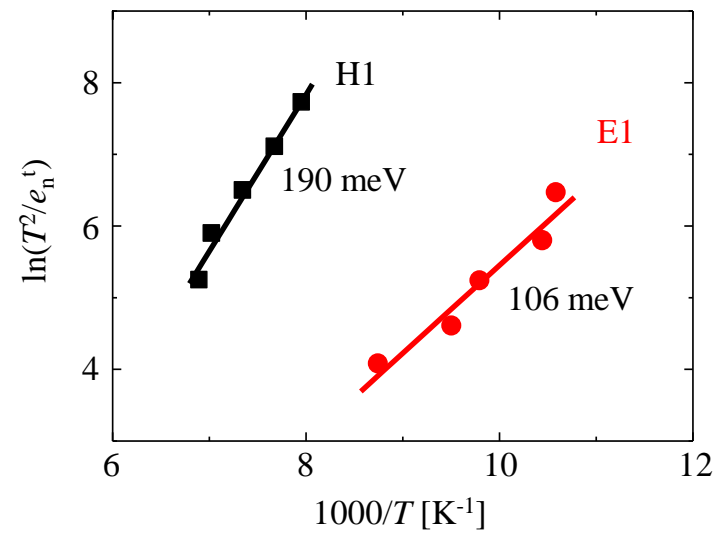

Fig. 5 


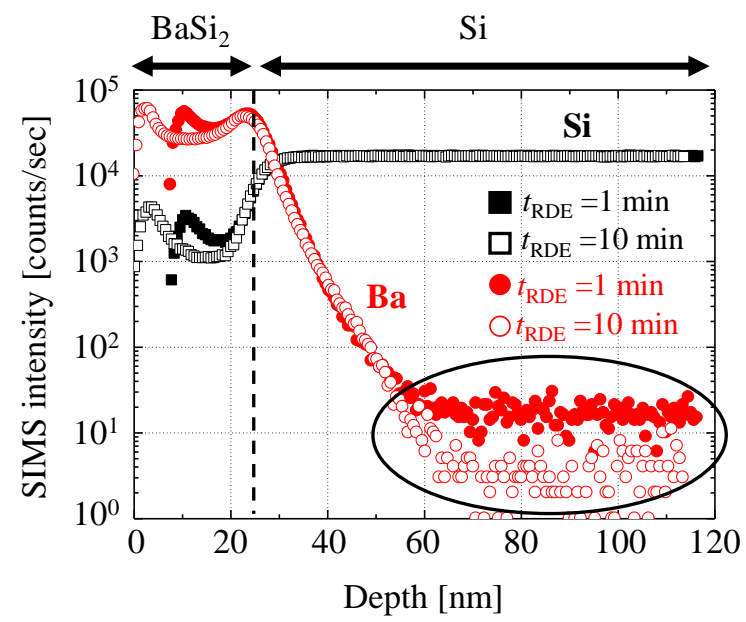

Fig. 6 
(a)

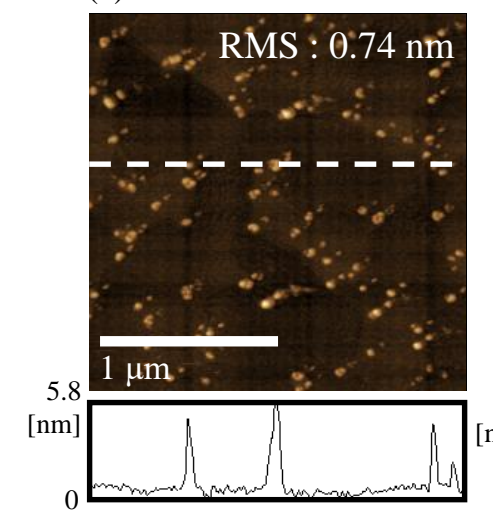

(b)

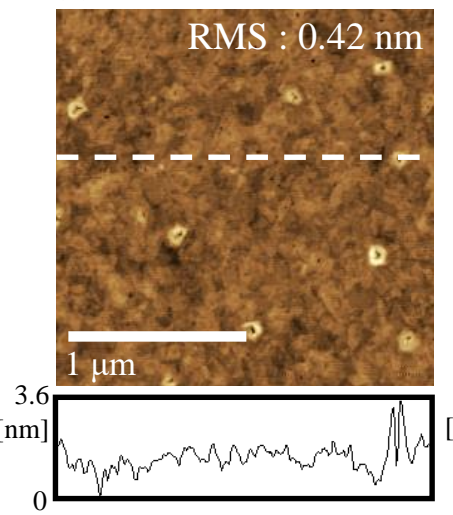

(c)

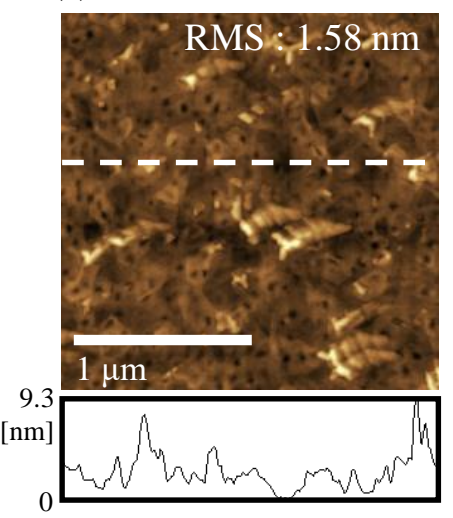

Fig. 7 

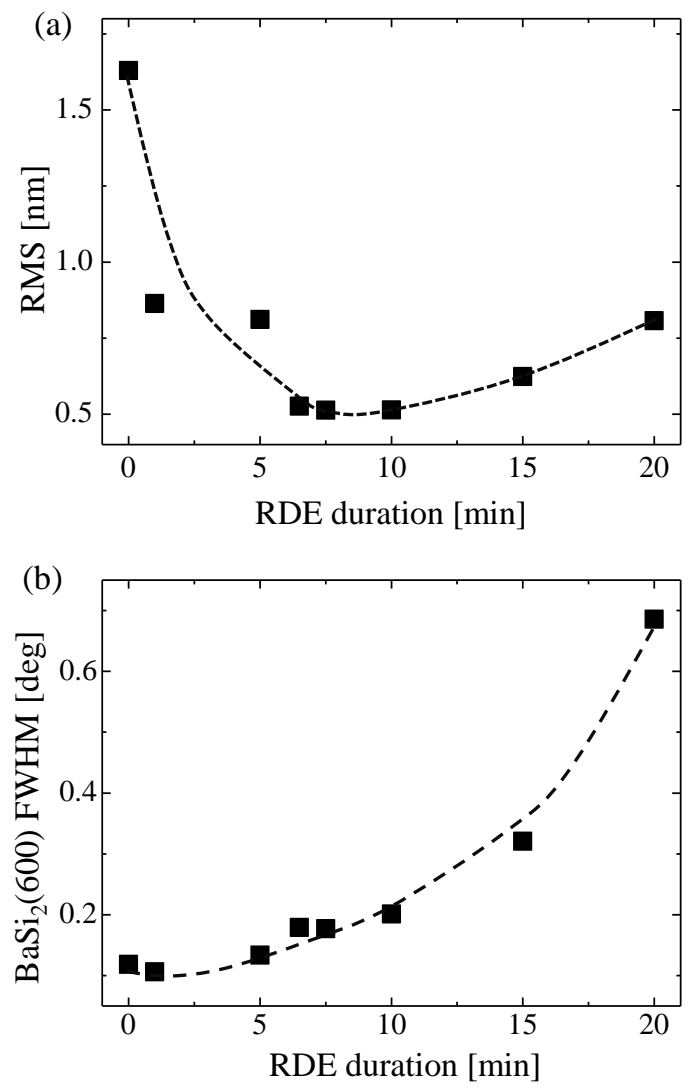

Fig. 8 

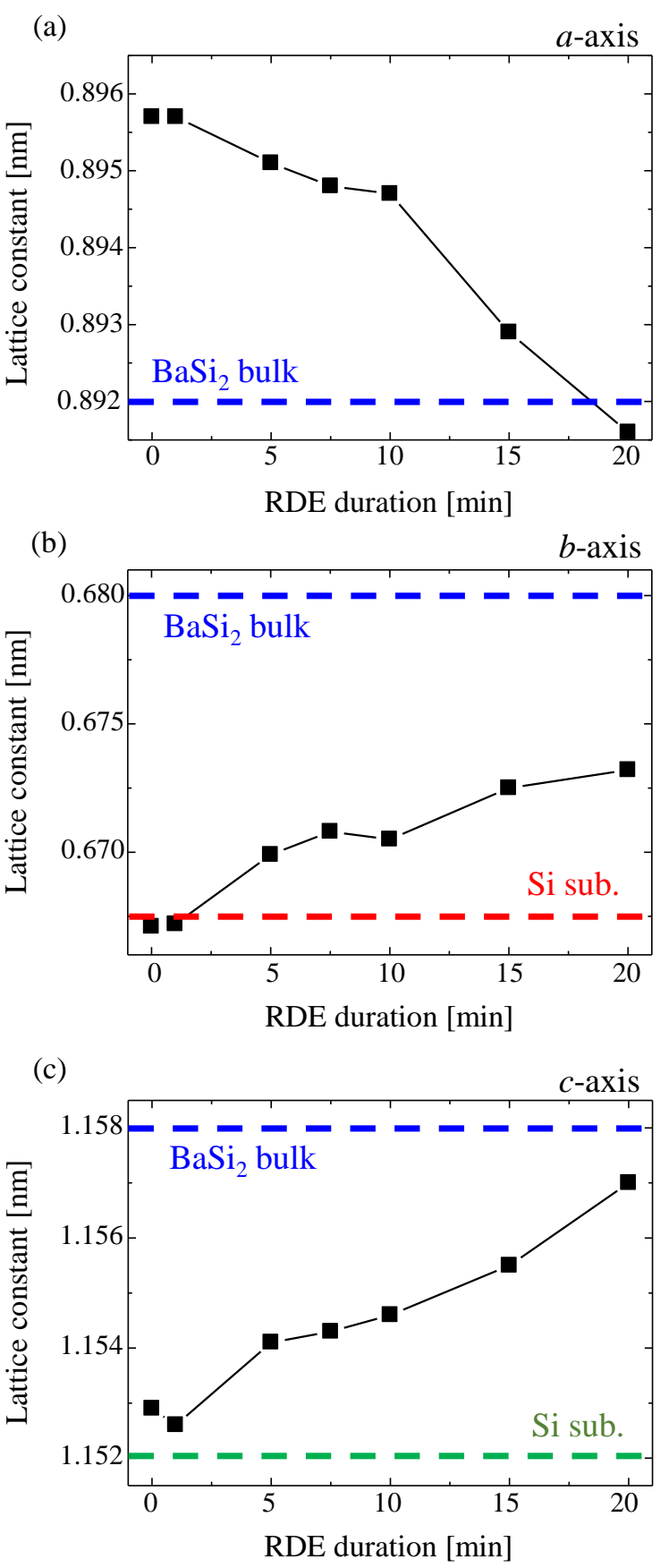

Fig. 9 